DOI: https://doi.org/10.15407/techned2018.05 $: \underline{015}$

\title{
INVESTIGATION OF THE THIN STRUCTURES INDUCED MAGNETOSTATIC FIELDS IN A THREE-DIMENSIONAL SPACE BY MEANS OF THE OF THE MODIFIED BOUNDARY ELEMENTS METHOD DEVELOPMENT
}

$\quad$ Journal
Publisher
ISSN
Issue
Pages

Tekhnichna elektrodynamika Institute of Electrodynamics National Academy of Science of Ukraine 1607-7970 (print), 2218-1903 (online)

No 5, 2018 (September/October)

$15-21$

\section{Authors}

V.M. Ryabenkiy ${ }^{*}$, I.I. Chudaykin ${ }^{* *}$, J.D. Targunakova ${ }^{* * *}$

Admiral Makarov National university of shipbuilding, Heroiv Ukrainy ave., 9, Mykolaiv, 54001, Ukraine, e-mail: golubkajulya@gmail.com

* ORCID ID : http://orcid.org/0000-0002-6998-746X

** ORCID ID : http://orcid.org/0000-0003-2417-9343

*** ORCID ID : http://orcid.org/0000-0003-0643-9412

\begin{abstract}
The methodology of the modified boundary elements method implementation and developing of the MBEM software package based on the mentioned method (which can be used for calculating and simulating induced magnetic fields of thin-walled structures in three-dimensional space) were proposed. Calculations of the magnetic field of a thin-walled cylindrical shell is performed using the developed method. The results of the calculations obtained with the help of
\end{abstract}


the modified boundary elements method - values of the resultant magnetic tension vector of a thin-walled cylinder, calculated by the MBEM software package are presented. The results were confirmed by the results obtained with the finite element method using ANSYS software; and the values of the magnetic potential calculated using the developed method were confirmed by analytical calculations. References 19, figures 4, table 1.

Key words: calculations of the scalar magnetic potential and $\mathrm{H}$-field vector of the thin-walled object induced magnetic field; modified Boundary Elements Method; methodology of implementation of the modified boundary element method and developing of the MBEM software package.

Received: 13.10 .2017

Accepted: 03.05 .2018

Published: 16.08 .2018

\section{References}

1. Aleksidze M.A. Solution of Boundary Value Problems by the Method of Expansion in Non-orthogonal Functions. Moskva: Nauka, 1978. 352 p. (Rus)

2. Bloh Yu.I. Interpretation of gravitational and magnetic anomalies. URL: http://sigma3d.com/ pdf/books/blokh-interp.pdf (Accessed 25.02.2018) (Rus)

3. Bulyichev A.A., Lygin I.V., Melikhov I.V. Numerical methods for solving direct problems of gravimetric and magneto-metric analyses. Moskva: Lomonosov Moscow State University, 2010. 164 p. (Rus)

4. Vladov M.L., Starovoytov A.V. Review of geophysical methods of research in solving engineering-geological and engineering problems. Moskva: GDD Production, 1998. 67 p. (Rus)

5. Danilov A.A. Tetrahedral and surface triangular mesh generation techniques. Scientific and 
Technical Journal of Information Technologies, Mechanics and Optics ITMO University. 2010. 1(65). Pp. 87-89. (Rus)

6. Krasnov I.P. On the solution of certain boundary value problems of the theory of harmonic functions. Differential Equations. 1975. Vol. XI. No 11. Pp. 2052-2066. (Rus)

7. Krasnov I.P. Calculated methods of ship magnetism and electrical engineering. Leningrad: Sudostroenie, 1986. 216 p. (Rus)

8. Krapivsky E.I., Nekuchaev V.O. Remote magnetometry of gas and oil pipelines. Ukhta: USTU, 2011. 142 p. (Rus)

9. Kornienko Yu.V. Mathematical modeling and analysis of the plane-spatial structural elements in CAD: Extended abstract of Dr. tech. sci. diss.: 05.13.12 / Odessa National Polytechnic University. Odessa. 2015. 170 p. (Rus)

10. Morozov V.A. Bank of models and methods for calculating electrostatic fields: thesis of kand. tech. sci. diss.: 05.09.05 / South-Russian State Polytechnic University (NPI) named after M.I. Platov. Novocherkassk, 2003. 137 p. (Rus)

11. Pashkovskiy A.I. Numerically analytical methods of standard elements for modeling stationary physical fields in linear piecewise-homogeneous and nonlinear media: Extended abstract of Dr. tech. sci. diss.: 05.13.18 / South-Russian State Polytechnic University (NPI) named after M.I. Platov. Novocherkassk, 2014. 36 p. (Rus)

12. Rezinkina M.M., Lobzhanidze L.E. Analysis of magnetic field of three-dimensional ferrous objects: Tekhnichna Elektrodynamika. 2011. No 1. Pp. 19-23. (Rus)

13. Ryabenkiy V.M., Chudaykin I.I., Targunakova J.D. Modified Boundary Elements Method and algorithm for solving problems of the thin structures induced fields in a three dimensional space. Informatsiini tekhnolohii ta kompiuterne modeliuvannia. 2017. No 1 (021). Pp. 192-199. (Ukr)

14. Starikov V.S. Engineering magnetometry in the stude of technical state of large diameter steel pipelines. Vestnik VGU. Seriia: Geologiia. No 3. 2016. Pp. 114-118. (Rus)

15. Tozoni O.V. The method of secondary sources in electrical engineering. Moskva: Energiia, 1975. 296 p. (Rus)

16. Hayrullin F.S. Calculation of thin-walled structures of complex shape on the basis of approximating functions with finite carriers. Kazan: KNITU, 2012. 176 p. (Rus)

17. Geuzaine C., Remacle J. User manual Gmsh. 2017. URL: http://gmsh.info/doc/texinfo/gm sh.html

. (Accessed

06.10.2017).

18. Holmes J.J. Reduction of a Ship's Magnetic Field Signatures. Arizona: Morgan \& Claypool Publishers, 2008. 68 p.

19. Katsikadelis John T. The Boundary Element Method for Engineers and Scientists. Academic Press, 2016. 464 p. 